\title{
Annular pancreas causing duodenal obstruction in an adult
}

\author{
Jie Lim, ${ }_{1}$ Johnathan Porter, ${ }_{1}^{1}$ Haren Varia, ${ }^{2}$ Stephen Pettit ${ }^{1}$
}

${ }^{1}$ General Surgery, Blackpool Teaching Hospitals NHS Foundation Trust, Blackpool, UK ${ }^{2}$ Radiology, Blackpool Teaching Hospitals NHS Foundation Trust, Blackpool, UK

\section{Correspondence to}

Mr Stephen Pettit,

stephenhpettit@btinternet.com

Accepted 27 April 2017

\section{DESCRIPTION}

A 35-year-old man was admitted following daily vomiting for 2 weeks. He reported bouts of unexplained vomiting over the preceding 10 years. Gastroscopy showed obstruction in the second part of the duodenum with normal mucosa on biopsy (figure 1). CT demonstrated dilation of the first part of the duodenum caused by narrowing of the

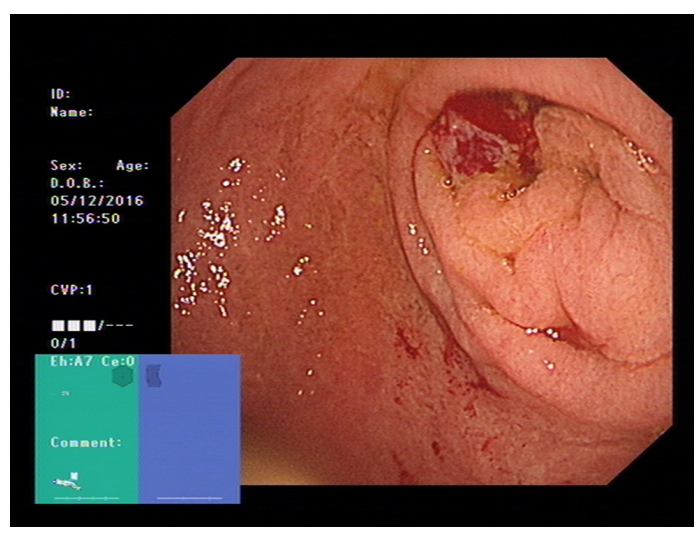

Figure 1 Gastroscopy image showing obstruction of the second part of the duodenum. The biopsy site is shown by an area of bleeding.

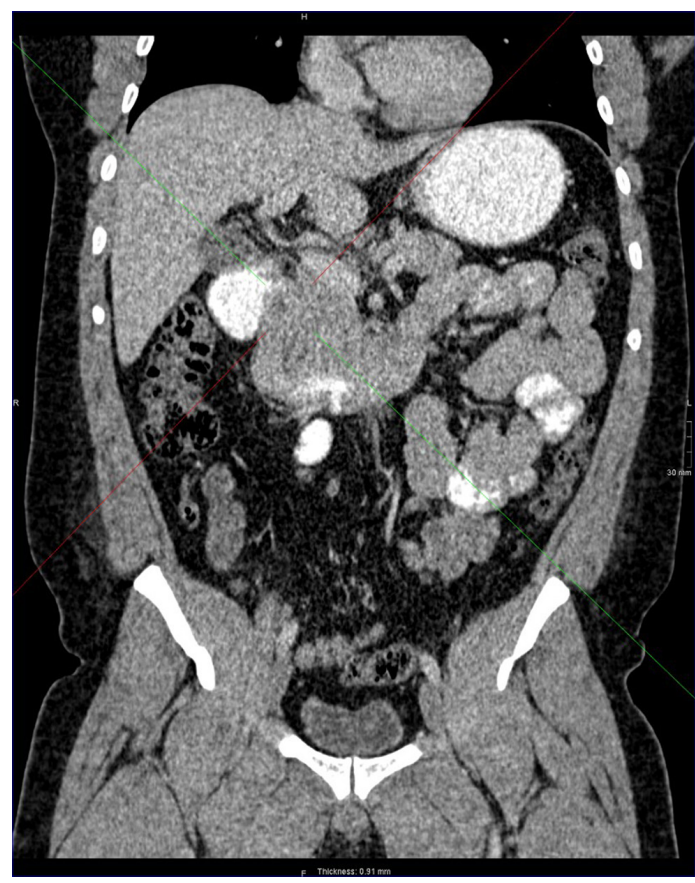

Figure 2 Reformatted coronal CT showing obstruction of the first part of duodenum caused by narrowing of the second part.

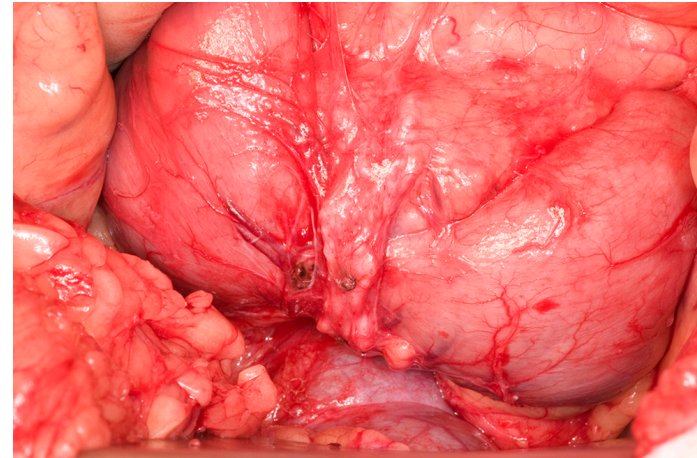

Figure 3 Operative photograph showing the annular pancreas surrounding and obstructing the second part of the duodenum.

second part (figure 2). There was no pancreatic mass. At laparotomy, a ring of pancreatic tissue was found encircling the second part of the duodenum causing obstruction (figure 3). This is a congenital abnormality known as annular pancreas. The annular pancreas was resected (figure 4). He was discharged 5 days after surgery and at subsequent outpatient review had no further vomiting. MRI 2 months after surgery showed an unobstructed duodenum (figure 5).

Annular pancreas occurs in 1 in 20000 of the population. It develops during the fifth week of embryonic development when two lobes of a bilobed ventral pancreatic bud migrate in opposite directions around the duodenum. This may be caused by faulty hedgehog signalling. ${ }^{1}$ Severe duodenal obstruction results in neonatal presentation. Moderate obstruction causes recurrent vomiting in adults usually between 20 and 50 years of age. Diagnosis may be made with gastroscopy,

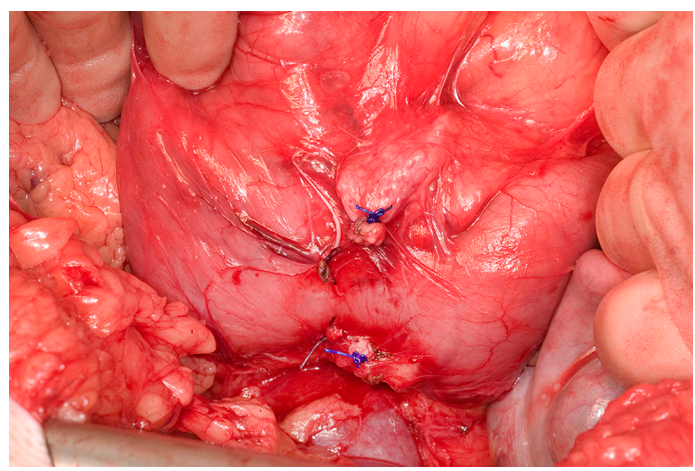

Figure 4 Operative photograph showing that the duodenal obstruction has been relieved by resecting the annular pancreas. 


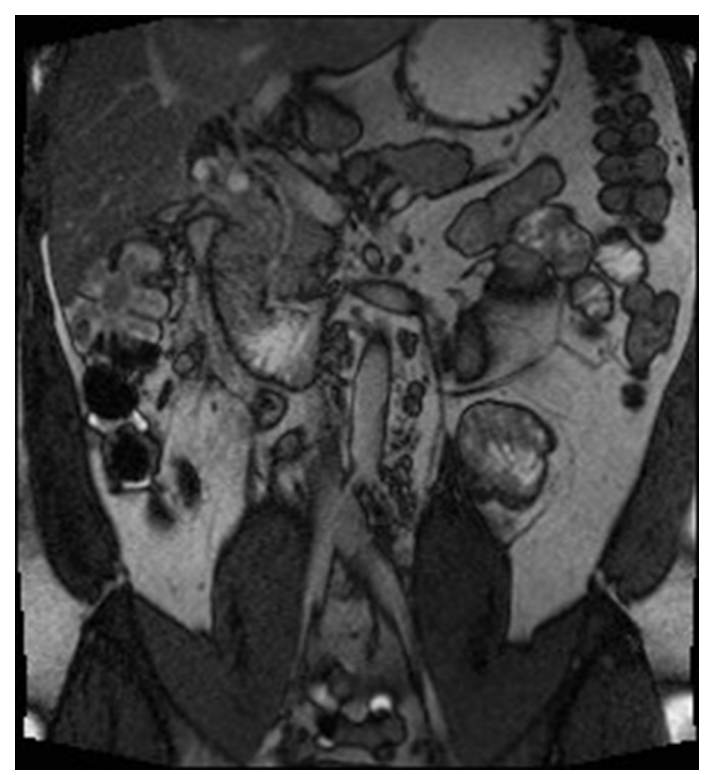

Figure 5 MRI 2 months after surgery showing an unobstructed duodenum.

$\mathrm{CT}$ and $\mathrm{MRI}^{2}$ or at laparotomy. Excision of the annular pancreas relieves the duodenal obstruction and avoids complications such as stomal ulceration, which occur with gastrojejunostomy, suggested as optimal treatment in historical reports.

Annular pancreas is uncommon but should be considered in the differential diagnosis of recurrent vomiting.

\section{Learning points}

- Annular pancreas is a rare congenital abnormality occurring in 1 in 20000 of the population.

- Annular pancreas can present with recurrent vomiting in adults.

- Duodenal obstruction caused by an annular pancreas can be cured by resecting the annular pancreas surrounding the second part of the duodenum.

Contributors JL, JP and SP identified this case as worthy of publication because of its clinical importance. HV undertook the radiological investigations. All authors were involved in the literature search and in writing up the case report.

Competing interests None declared.

Patient consent Obtained.

Provenance and peer review Not commissioned; externally peer reviewed.

(C) BMJ Publishing Group Ltd (unless otherwise stated in the text of the article) 2017. All rights reserved. No commercial use is permitted unless otherwise expressly granted.

\section{REFERENCES}

1 Klieser E, Swierczynski S, Mayr C, et al. Differential role of hedgehog signaling in human pancreatic (patho-) physiology: an up to date review. World I Gastrointest Pathophysiol 2016;7:199-210.

2 Türkvatan A, Erden A, Türkoğlu MA, et al. Congenital variants and anomalies of the pancreas and pancreatic duct: imaging by magnetic resonance cholangiopancreaticography and multidetector computed tomography. Korean J Radiol 2013:14:905-13.

3 Thomford NR, Knight PR, Pace WG, et al. Annular pancreas in the adult: selection of operation. Ann Surg 1972;176:159-62.

Copyright 2017 BMJ Publishing Group. All rights reserved. For permission to reuse any of this content visit

http://group.bmj.com/group/rights-licensing/permissions.

BMJ Case Report Fellows may re-use this article for personal use and teaching without any further permission.

Become a Fellow of BMJ Case Reports today and you can:

- Submit as many cases as you like

- Enjoy fast sympathetic peer review and rapid publication of accepted articles

- Access all the published articles

Re-use any of the published material for personal use and teaching without further permission

For information on Institutional Fellowships contact consortiasales@bmjgroup.com

Visit casereports.bmj.com for more articles like this and to become a Fellow 